\title{
THE EFFECT OF PACKAGING COLOR SCHEME ON PERCEPTIONS, PRODUCT PREFERENCES, PRODUCT TRIAL, AND PURCHASE INTENTION
}

\author{
Wirania Swasty ${ }^{*}$, Mediany Kriseka Putri ${ }^{2}$, Mohammad Isa Pramana Koesoemadinata ${ }^{3}$, \\ Ahmad Nur Sheha Gunawan ${ }^{4}$ \\ 1,3,4 School of Creative Industries, Telkom University, Jl. Telekomunikasi No.1, Terusan Buahbatu, Bandung, \\ Jawa Barat 40257, Indonesia \\ ${ }^{2}$ School of Economics and Business Telkom University, Jl. Telekomunikasi No.1, Terusan Buahbatu, \\ Bandung, Jawa Barat 40257, Indonesia \\ Email: ${ }^{*}$ wirania@telkomuniversity.ac.id, ${ }^{2}$ mediany.kris@gmail.com, ${ }^{3}$ dronacarya@telkomuniversity.ac.id, \\ ${ }^{4}$ ahmadnursheha@telkomuniversity.ac.id \\ *Corresponding author
}

\begin{abstract}
This study aimed to understand the effect of different color scheme in perceptions and food product preference, product trial, and purchase intention. Using quantitative approach, the questionnaires data were cross tested by chi square and one-way ANOVA. The study found there were no significant differences between the price perception, the perceived quality, product preferences, product trial and intense to buy in the different color schemes, except white dominant color in perceived quality aspect. Respondents assessed the use of monochrome color schemes tended to have higher price perceptions and higher quality than white, yellow, analog, and complementary color schemes. It was expected to be a reference to provide an understanding of packaging design strategy especially food products by using color scheme.
\end{abstract}

Keywords: Color scheme, packaging, product preference, perception, SME

\section{Introduction}

Consumers' attitudes and preferences toward the brand can be influenced by using the visual design element such as its packaging (Husić-Mehmedović, Omeragić, Batagelj, \& Kolar, 2017; Velasco, Pathak, Woods, Corredor, \& Elliot, 2020). Positive effect can be achieved by manipulating one or more packaging variables, including packaging color. In the retail industry itself, products are competing for the attention of buyers. Whether realized or not, color can affect a person in buying goods. The response to color is a blend of culture and personal experience accumulated throughout his life (Triedman, 2015). On the other hand, the more familiar and efficient the process, the more likely it is to be driven by mental processes outside of consciousness. Often the purchase action is carried out without involving one's awareness, but instead with the packaging branding and the placement on a consistent shelf (Graves, 2015). Therefore, in deepening the color, it is important to understand the responses of a person and the population group psychologically and socially.

Along with the government support, small and medium enterprises (SMEs) from the creative industries are increasingly emerging. One of the subsectors of the creative industry that is fostered by many SME practitioners is the culinary industry (food and beverages). However, many SMEs in the city of
Bandung lacked both managerial and technical aspects. Some of the common problems faced by SMEs are in the field of marketing, production, and finance. In the field of marketing itself, SMEs experience branding, logo and packaging problems (Swasty, 2015; Windharto, 2014).

Meanwhile, good packaging design can also be means of visual communication product content and product quality. This is also confirmed in some previous studies. An approved packaging can be an effective marketing tool that can increase sales in retail places; triggering the purchase decision process (Mohebbi, 2014). With the increasing number of products offered in the market, naturally SME products are facing fierce competition. For that reason, the research on the packaging of SMEs products to have competitive advantage is needed. In addition, the results of this study can also be used as a reference for other similar SME products; one of which determines the colors to be marketed on certain segments of Social Economic Status (SES). By predicting consumer behavior, companies can predict consumer tastes (Sangaji \& Sopiah, 2013).

From the prior study (Swasty, Koesoemadinata, Gunawan, \& Putri, 2019), it was revealed that the most important components in packaging design were packaging shape (36\%), followed by illustrations of images/photos on packaging (34\%) and packaging colors $(25 \%)$. Despite the color rank three as the 
important components from our pilot study, however many extant studies emphasize the influence of color in purchase intentions (Beneke, Mathews, Munthree, \& Pillay, 2015; Huang \& Lu, 2016; Yu et al., 2018). Thus, it is worth to examine the colors in the packaging designs associated with perceptions and preferences. It was also revealed that student respondents most liked the illustrated images as illustrations on banana chips packaging (68\%) in addition to a scheme of product photos and illustrated images or just photos of banana chips. This will be a visual concept illustration on the prototype of banana chips packaging to be the main research object.

Although some research has been carried out on color preferences of packaging, very little attention has been paid to the SMEs food products. This study focuses on the packaging color of the SMEs food products. Banana chips were selected as the objects of study because the color of packaging is quite varied (after surveyed in some retails in Bandung). When compared to cassava chips which are predominantly red as the color of packaging, banana chips have more varied color and harmony colors.

The formulations of this research problem were as follows: firstly, how are colors and color schemes perceived by adolescent consumers? Secondly, what is the relation between color perceptions and product preferences on adolescent consumers with A-C Social Economic Status (SES)? Therefore, this study aims to explore colors and color schemes perceived by adolescent consumers; as well as to identify the correlation between color perceptions and product preferences on adolescent consumers with social economic status (SES).

\section{Definition and Function of Packaging}

Packaging is the activity of designing and producing containers or wrappers for a product (Keller, 2013). Packaging is categorized into three types as follows: Primary packaging, direct contact with the product contents; Secondary packaging as wrapper of primary packaging and an advertising medium; Shipment packaging, used for shipping and storage purposes (Kotler \& Keller, 2016). Preventing damage to food quality caused by environmental influences, packaging can also contribute to effective delivery, sales, and consumption. The main function of the packaging is to maintain the durability and safety of the delivery of food products until they are consumed. The second main function of the packaging is marketing (Wahyudi \& Satriyono, 2017).

Packaging viewed from two perspectives - both the company and the customer, has the following functions: identifying the brand and differentiate from other brand (Singh, 2018), conveying descriptive and persuasive information about the product offered (Ribeiro, Carneiro, Ramos, Patterson, \& Pinto, 2018), protecting the product in the distribution need, assisting for storage, and increasing product consumption (Kotler \& Keller, 2016). In addition to fulfilling the functional aspects, the packaging must also consider the aesthetic aspects, both in shape, size, color, materials and other graphic elements (Swasty, 2016).

\section{Theory of Colors}

Many color spaces are used to describe colors, one of them is the HCL (hue, chroma, luminance) model. Hue is the pigment or the light wavelength, identified by the name, such as yellow, green, blue. Chroma is the saturation, measured as a percentage, with $100 \%$ is the fully saturated color. Luminance shows the value or the brightness, its whiteness or blackness, where $0 \%$ is always black and $100 \%$ is always pure white (Greiner \& Stephanides, 2020). Scientists agree that there are two types of colors. Subtractive colors are colors that come from pigments - Cyan, Magenta and Yellow are called CMY color models. If all pigment colors are mixed, it will get a blackish brown color. The additive primary colors which consist of red, green, and blue, are often called the RGB color model. If all spectrum colors of light are mixed, then white will be produced. Brewster classifies the color into four colors which are primary, secondary, tertiary and neutral. Johannes Iten creates a color circle and formulates a color balance theory consisting of dyadic (complementary), triadic (Split complementary), and tetradic (Triedman, 2015) which are called color harmony or color combination (Gong \& Lee, 2019).

Scientists classify colors into two main extremes of color: hot and cold colors. Hot or warm colors are red, orange, brown and yellow. These colors are active, stimulating, positive and aggressive, and often associated with fire, blood and the sun. While cold or cool colors are blue, green and purple. These colors are calm, safe, reverse, and negative, also associated with water, the sky and mountains (Kauppinen-Räisänen \& Jauffret, 2018; Triedman, 2015).

\section{The Roles of Color in Packaging Design}

Many products are recognized from packaging designs, and a color is an important element in building brand image (Baxter, Ilicic, \& Kulczynski, 2018; Cunningham, 2017; Dalgin, Sraiheen, \& Akcay, 2018; $\mathrm{Kim}, 2019)$. Consistent color usage in a packaging 
design or a product line makes a color, as a brand identifier, can prevent competitors from deliberately duplicating product wrappings (Klimchuk \& Krasovec, 2012). Color packaging can help branding a product. For example, green bottle cans packaging of Sprite or blue bottles plastic of Aqua have successfully built the brand identity of the company so that the brand is embedded in the minds of consumers.

The color of the packaging is related to the content of the product (Garaus \& Halkias, 2020). In addition to providing information about its products, packaging colors play a role in communicating products. The red color gives the message that the product tastes spicy, while the blue color gives the product a cold message. In addition, colors also communicate the content of the product. For example, green tea flavored beverage products use green packaging, while brown packaging shows the taste of coffee. In addition to capture the attention of consumers and affecting preferential judgements, packaging colors can communicate information about the product at the point of purchase (Mohebbi, 2014). Moreover, colors can identify products, differentiate a product with a competitor's product especially in the retail industry. Appropriate selection and use of colors can differentiate product variety - the composition, taste or flavor variant - in a product line (Klimchuk \& Krasovec, 2012). A color - as a marketing tool - can be a persuasive force. As a visual element, colors can attract attention, cool the eyes, play a role in determining the success of a product (Triedman, 2015). Packaging colors can affect consumer perceptions of the product (Keller, 2013; Wei, Ou, Luo, \& Hutchings, 2012).

Perception arises from sensation (rapid response of the senses to basic stimuli). According to Stanton (in Sangaji \& Sopiah, 2013), perception is a meaning that is linked based on past experiences and stimuli received through the five senses. The perception that someone formed influences the mind and the environment. The process of perception includes (1) Perceptual selection, the consumer capturing and selecting a stimulus based on a series of psychologically owned; (2) Perceptual organizations, consumers group information into a comprehensive sense of understanding and action; (3) Perceptual interpretation, based on the use of past experience stored in long-term memory (Sangaji \& Sopiah, 2013). Pride and Ferrel (in Sangaji \& Sopiah 2013) divides factors that influence consumer behavior into three groups: (1) personal factors including demographic factors (sex, age, expenditure); (2) Psychological factors include perceptions; (3) Social factors include social classes.
In addition, extant literature suggest that color can also be used as a signal for price or quality (Beneke $e t$ al., 2015; Singh, 2006). Price perception is consumer's willing to pay for its cost fulfill its requirement (Mirza \& Ali, 2017). Perceived quality is the customer's opinion toward the overall quality of a product brand or a service (Shakeel, 2015). Therefore, hypothesis in this case can be developed as follows:

$H_{l}$ : There is a significant difference between the price perception in different color schemes.

$\mathrm{H}_{2}$ : There is a significant difference between the quality in different color schemes.

In packaging design, colors have roles, as the brand identity, communicative and persuasive design. The selection of colors and attractive schemes on product packaging can make the product preferred by consumers than similar competitors' products. A color on a packaging is a stimulus in the beginning of the consumer purchase decision process. Stimulation is influenced by environmental factors which are psychology and consumer characteristics. This study limits the perceptions and social classes of consumers. These perceptions and social classes can influence the buying decision process in the stage of seeking information and alternative evaluation; which will bring consumers to the formation of likes or preferences (Sangaji \& Sopiah, 2013). Engel et al. (in Sangaji \& Sopiah, 2013) put forward five stages of consumer behavior in making purchasing decisions, which are: (1) introduction of needs; (2) information search; (3) evaluation of alternatives, the process of evaluating product or brand choices by comparing selected brands. This will lead consumers to the formation of preferences and subsequent buying desire; (4) buying decision; (5) results (satisfied or not satisfied).

Purchase intention is influenced by the product price and the brand's service quality (Mirza \& Ali, 2017). Another study points out that consumers' perception and purchase intention can also be influenced by package color (Huang \& Lu, 2016; Witkowska, 2018; Yu et al., 2018). In this case, product preference as well as product trial and purchase intention can be created through packaging design (DuPuis \& Silva, 2011). Color is one of the fundamental elements that have a psychological effect on the consumer's mind and its purchasing behavior (Babolhavaeji, Vakilian, \& Slambolchi, 2015). Study by Javed and Javed (2015) emphasize that consumers' preference was based on color scheme than on time constraints. The study suggests that business owners, brand managers, and marketers cannot ignore the significance of packaging color schemes in bringing 
variation in consumers' buying preferences. Previous research on color perception and preferences studies point out that women prefer softer colors whereas men prefer bold colors when it comes to hues, shades, and tints (Karthikeyan \& Joy, 2018). follows:

Therefore, the hypothesis can be developed as

$H_{3}$ : There is a significant difference between the product preference in different color schemes.

$H_{4}$ : There is a significant difference between product trial in different color schemes.

$H_{5}$ : There is a significant difference between purchase intention in different color schemes.

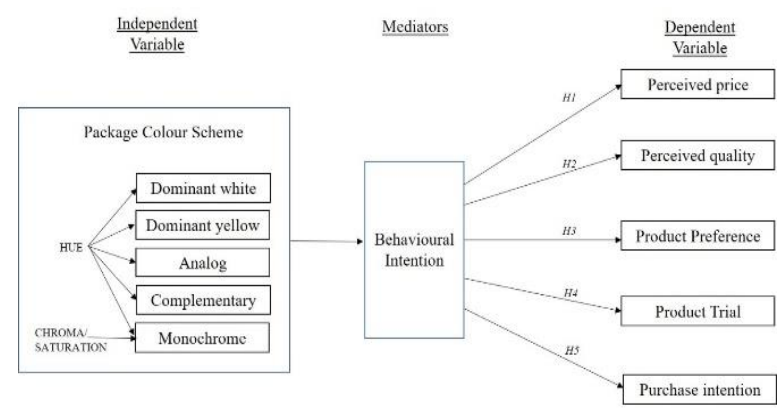

Figure 1. The conceptual research framework

\section{Research Methods}

This study used a quantitative approach. The data collecting was begun by the literature study from reference books, scientific journals, and similar research to find the theory as the initial foundation in searching for research problems and what aspects will be measured or compared. To retrieve primary data, observation techniques are carried out through a market observation of the existing packaging. This observation aims to collect data related to the packaging design that becomes the object of the research. The study was begun with a pilot study as a trial run that was undertaken in preparation for this study. The collection of pilot study was carried out by spreading the questionnaires online (via Google Form). Questionnaires were distributed to undergraduate students aged 17-25 years. The results of these questionnaires became a reference for the creation of banana chips Primary Display Panel (PDP) packaging prototype as the object of study (Swasty et al., 2019).

The second stage was begun with the creation of various schemes of colors for banana chips packaging prototypes that are dominant white color, yellow color, analog colors scheme, complementary, and monochrome. Prior study on color packaging and consumer perception (Martinez, Silva, Martinez, \& Abreu, 2018; Mead \& Richerson, 2018; Yu et al.,
2018) have used an experimental method to test the hypotheses. Hence, this study used an experimental color scheme of packaging as prior research suggest. The foundation for designing the different color scheme of packaging prototype research was based on the results of the pilot study (Swasty et al., 2019). The next stage was the data collection with the spread of the questionnaires offline.

\section{The Participants}

Questionnaires were distributed offline to the prescribed respondents. The target population were undergraduate visual communication design students in six large public and private universities in Bandung, Indonesia. Our justifications are design students can predict, assess, and appreciate a design work, as well as have knowledge in color schemes. Moreover, design students are chosen as participants as this study used convenience sampling and design students are more approachable by researchers. Not to mention, students are active consumers in buying snack foods. One of the variables questioned was the demographic factor of monthly expenditure. The demographic data was later cross-examined with questions such as color perception, price, quality, preference and purchase intention. The results of these questionnaires were expected to answer the formulation of this research problems. The respondent profile is described in Table 1.

Table 1

Respondents' Profile

\begin{tabular}{lccc}
\hline \multicolumn{1}{c}{ Item } & & Freq. & \% \\
\hline Age & 18 & 3 & $2.7 \%$ \\
& 19 & 19 & $17.3 \%$ \\
& 20 & 50 & $45.5 \%$ \\
& 21 & 26 & $23.6 \%$ \\
& 22 & 5 & $4.5 \%$ \\
& 23 & 6 & $5.5 \%$ \\
Gender & 24 & 0 & 0 \\
Study & 25 & 1 & $0.9 \%$ \\
Program & Male & 56 & $51 \%$ \\
Univ. & Female & 54 & $49 \%$ \\
& VCD & 110 & $100 \%$ \\
& & & \\
& Maranatha & 10 & $9.1 \%$ \\
& ITHB & 10 & $9.1 \%$ \\
& ITB & 10 & $9.1 \%$ \\
SES & ITENAS & 17 & $15.5 \%$ \\
& Widyatama & 13 & $11.8 \%$ \\
& Telkom & 50 & $45.4 \%$ \\
& C-D & 86 & $78.2 \%$ \\
& A-B & 24 & $21.8 \%$ \\
\hline
\end{tabular}


Respondents who participated in this study were 110 undergraduate students of Visual Communication Design (VCD) department from six large universities in Bandung, Indonesia. Those six large and wellknown universities in Bandung were selected as they have Visual Communication Design department. The age of respondents ranged from 18 to 25 years, with the majority of respondents 20 years old by $45.5 \%$.

The current definition of Socio Economic Status (SES) has been adopted since the 1970s, using a single measure: Routine Monthly Household Expenditure (Nielsen, 2013). The ABCDE classification by Nielsen Admosphere is defined as the categorization of household socioeconomic scores; which consists of 8 categories A, B, C1, C2, C3, D1, D2 and E (Nielsen, 2017). In this case, from 110 respondents, it is known as 86 respondents or $78.2 \%$ have expenditure of IDR $600,000-1,750,000$ and categorized as SES C-D and the remaining 24 or $21.8 \%$ have expenses of IDR 1,750,000-3,500,000 which are categorized as SES A$B$. These SES (A-B and C-D) are the control group.

\section{Procedure, Stimulus and Measurement}

Questionnaires in Bahasa as a local language were distributed face-to-face along with prototypes using convenience non-probability sampling method, where participants are selected based on some criteria. For stimulus, 15 packaging prototypes were shown to all respondents $(N=110)$ with three different variant flavours (Choco-latte, Minty Vanilla, and Sour 'n Salty), and five different color schemes (dominant white, dominant yellow, monochromatic, analog and complementary color). Each of five different color schemes were shown to respondent for 30 seconds as the basis for answering the questionnaires. First, three schemes of dominant white PDP packaging were shown for all respondents to rate. The white color here symbolizes the color of accessible and affordable SMEs product packaging (Ampuero \& Vila, 2006).

Afterwards, the three schemes of dominant yellow PDP packaging were shown, where yellow represents the banana color. Then, three schemes of PDP packaging of monochrome color schemes, followed by the analogous color scheme and complementary color scheme. The color of the packaging was made differently by the colors of the variant flavors, where the chocolate color represents the Choco-Latte flavor, the tosca color represents the Minty-Vanilla flavor, and the leaf green color represents the Sour 'N Salty flavor. The color schemes were taken from the color representatives of three different flavor variants, and the selected blend of color schemes (Figure 2).

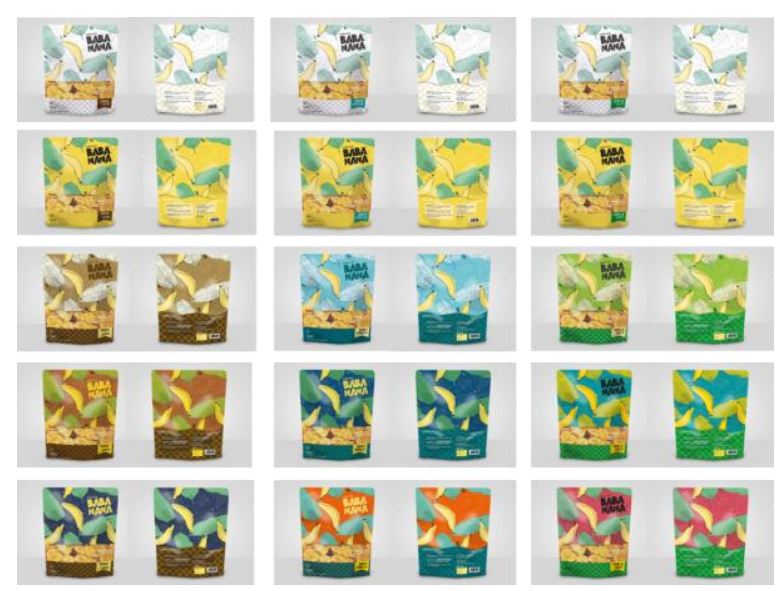

Figure 2. The packaging dominant white, dominant yellow, monochrome color scheme, analog, and complementary

The questionnaire begun with a color blind test (Ishihara, 1972). This was to ensure the respondent has a normal color vision. The questionnaire was divided into three sections. Section one began with respondents' information such as age, gender, study program and university, monthly expenditure, the most like and dislike colors. In section two, respondents were asked about the most interesting element of packaging and the most important factor in choosing packaging color. In section three, respondents evaluated the stimulus as above mentioned (Figure 2). This section contained five semantic differential statements, such as price perception ("Cheap" - "Expensive"), quality perception ("Bad" - "Good"), product preference, product trial and intense to buy ("Strongly Disagree" - "Strongly Agree") using a nine-point Likert Scale. In addition, the respondents were asked to assess the acceptable price for each packaging color in Indonesia Rupiah (IDR). In the last question, they must select three product attributes related to each packaging color, such as sweet, fun, pure, trusted, active, creative, fresh, etc.

\section{Data Analysis}

After the distribution of the questionnaires, the study proceeded to the stage of processing and data analysis. Data analysis was conducted by crosstab test and chi-square test using SPSS software between monthly expenditures with each color ranging from dominant white, dominant yellow, monochrome color scheme, analog color scheme and complementary color scheme. Spending per month was associated with the socio-economic status (SES) of respondents, where IDR 1,750,000 to IDR 3,500,000 was classified as AB SES (middle-up status), while expenses from IDR 600,000 to IDR 1,750,000 were classified as CD 
SES (middle-low status). Description of expenditures for later was grouped A-B SES and C-D SES. To see the significant differences between price perception group and quality in the different color schemes, oneway ANOVA test was conducted.

\section{Results and Discussion}

\section{Result of Crosstab Test and Chi-Square Test The Dominant white color}

Based on the result of crosstab on dominant white color conducted between monthly routine expenditure (showing social economic status or SES) with the product price perception, it was known there were two tendencies of respondent perception, i.e. cheap and expensive. Of 86 respondents SES C-D or $78.2 \%$ have expenditures of IDR 600,000-1,750,000 known as 26 people or as much as $23.6 \%$ said the price in the category was quite expensive. While from 24 people with SES A-B or $21.8 \%$ of respondents who have expenses of IDR $1,750,000-3,500,000$, the majority of respondents, as many as 10 people or $9.1 \%$ rated the price of products in the category was moderate.

From 86 respondents SES C-D, identified as 32 people or $28.9 \%$ have perception of quality in good category. While from 24 people SES A-B, as many as 8 people or by $6.8 \%$ have the perception of dominant white color packaging quality in the category of very good quality. Of the 86 respondents SES C-D, it was recognised that the majority of 27 people or $28.1 \%$ have expressed approval of interest in products with dominant white packaging. Similarly, from 24 people with SES A-B, 9 people or $7.9 \%$ stated the same agreement.

Of the 86 respondents with SES C-D, it was known that the majority of 23 people or as much as $21.1 \%$ have expressed the agreement to tried products with dominant white packaging. While from 24 people with SES A-B, the majority as many as 10 people or $6.5 \%$ said they really wanted to try the product. Furthermore, it was known from 110 respondents, the majority of both SES C-D and SES A-B agreed to buy the product that are 31 people (28.2\%).

Based on Chi-Square test result (Table 2), it was identified that cross test result between expenditure and price of dominant white color has probability value above $0.05 \%(0.622>0.05)$. It means that the expenditure or Social Economic Status (SES) has no significant relation to price perception if the study takes the error rate of $5 \%$ and $10 \%$ because the probability value is $0.622>0.1$. Similarly, the expenditure or Social Economic Status (SES) has no significant relationship to the preference of the product, the intention to try the product (product trial), and purchase intention. However, it has a significant relationship on the perceived quality if the study takes a $10 \%$ error rate because the probability value is $0.093<0.1$.

\section{The Dominant Yellow Color}

Based on the results of crosstab in dominant yellow color conducted between monthly routine expenditure (showing social economic status) with product price perception, it was known from 86 respondents SES C-D, the majority of 28 people or $25.5 \%$ have price perception in the category quite expensive. While from 24 people SES A-B as many as seven people or as much as $6.4 \%$ have perception of product price in medium category.

Of 86 respondents SES C-D, as many as 28 people or $25.5 \%$ have perception of quality in good category. While from 24 people SES A-B, as many as 12 people or by $11 \%$ have the perception of yellow color packaging quality in the category of good and very good. Furthermore, from 110 respondents both SES C-D and SES A-B, it was known that the majority of 26 people or equal to $23.6 \%$ were both expressing the intention to buy the product the yellow packaging. In dominant yellow color, expenditure or Social Economic Status (SES) has no significant relationship to price and quality perception as well as product preference, product trial, and purchase intention. It is good if the research takes the error rate of $5 \%$ or $10 \%$

Table 2

Pearson Chi-Square Tests on Social Economic Status and Color Scheme

\begin{tabular}{|c|c|c|c|c|c|c|c|c|c|c|c|c|c|c|c|}
\hline \multirow[b]{2}{*}{ Item } & \multicolumn{3}{|c|}{ dominant white } & \multicolumn{3}{|c|}{ dominant yellow } & \multicolumn{3}{|c|}{$\begin{array}{c}\text { monochrome color } \\
\text { scheme }\end{array}$} & \multicolumn{3}{|c|}{$\begin{array}{c}\text { analogous color } \\
\text { scheme }\end{array}$} & \multicolumn{3}{|c|}{$\begin{array}{l}\text { complementary } \\
\text { color scheme }\end{array}$} \\
\hline & Value & & $\begin{array}{c}\text { Asymp. } \\
\text { Sig. (2- } \\
\text { sided) }\end{array}$ & Value & $d f$ & $\begin{array}{l}\text { Asymp. } \\
\text { Sig. (2- } \\
\text { sided) } \\
\end{array}$ & Value & $d f$ & $\begin{array}{l}\text { Asymp. } \\
\text { Sig. (2- } \\
\text { sided) } \\
\end{array}$ & Value & $d f$ & $\begin{array}{c}\text { Asymp. } \\
\text { Sig. (2- } \\
\text { sided) }\end{array}$ & Value & $d f$ & $\begin{array}{l}\text { Asymp. } \\
\text { Sig. (2- } \\
\text { sided) } \\
\end{array}$ \\
\hline Price Perception & $6.227^{\mathrm{a}}$ & 8 & 0.622 & $5.438^{\mathrm{a}}$ & 6 & 0.489 & $6.422^{\mathrm{a}}$ & 8 & 0.600 & $12.822^{\mathrm{a}}$ & 8 & 0.118 & $1.846^{\mathrm{a}}$ & 7 & 0.968 \\
\hline Perceived Quality & $10.847^{\mathrm{a}}$ & 6 & 0.093 & $3.681^{\mathrm{a}}$ & 5 & 0.596 & $3.254^{\mathrm{a}}$ & 6 & 0.776 & $10.764^{\mathrm{a}}$ & 7 & 0.149 & $2.182^{\mathrm{a}}$ & 6 & 0.902 \\
\hline Product Preference & $12.613^{\mathrm{a}}$ & 8 & 0.126 & $6.158^{\mathrm{a}}$ & 7 & 0.521 & $7.223^{\mathrm{a}}$ & 8 & 0.513 & $12.143^{\mathrm{a}}$ & 8 & 0.145 & $8.663^{\mathrm{a}}$ & 8 & 0.371 \\
\hline Product trial & $6.786^{\mathrm{a}}$ & 8 & 0.560 & $8.560^{\mathrm{a}}$ & 8 & 0.381 & $4.184^{\mathrm{a}}$ & 7 & 0.758 & $9.187^{\mathrm{a}}$ & 8 & 0.327 & $4.646^{\mathrm{a}}$ & 7 & 0.703 \\
\hline Purchase Intention & $3.614^{\mathrm{a}}$ & 7 & 0.823 & $3.549^{\mathrm{a}}$ & 8 & 0.895 & $6.082^{\mathrm{a}}$ & 8 & 0.638 & $8.729^{\mathrm{a}}$ & 8 & 0.366 & $5.905^{\mathrm{a}}$ & 8 & 0.658 \\
\hline
\end{tabular}


because all probability values are greater than 0.10 (see Table 2).

\section{Monochrome Color Scheme}

Based on the results of crosstab in monochrome color scheme between routine monthly expenditure (showing social economic status) with product price perception, it was known from 86 respondents SES C$\mathrm{D}$, the majority of 24 people or $21.8 \%$ have price perception in the expensive category. While from 24 people SES A-B as many as six people or 5.5\% have perception of product price in very expensive category. Of the 86 respondents SES C-D, it was identified as 25 people or as much as $22.7 \%$ have perceptions of quality in good category. While from 24 people SES $\mathrm{A}-\mathrm{B}$, as many as nine people or by $8.2 \%$ have a quality perception of monochrome color scheme packaging in the category of very good quality.

Of the 110 respondents, a majority of 27 people or $24.5 \%$ of both SES A-B and SES C-D expressed approval of interest in products with monochrome color scheme packaging. Similarly, both in SES C-D and SES A-B, it was found that a majority of 32 people or $29.1 \%$ stated that they wanted to try the monochrome color scheme packaging. Furthermore, of 86 respondents SES C-D, the majority of 18 people or $16.4 \%$ were neutral to the statement wanting to try the monochrome color scheme product packaging seven majority of seven people or $6.4 \%$ agreed to buy the product.

In monochrome color scheme, expenditure or Social Economic Status (SES) has no significant relationship to perception of price and quality, as well as product preference, product trial, and purchase intention; even if the research takes the error rate of 5\% or $10 \%$ because the probability value is greater than 0.10 (see Table 2).

\section{Analogous Color Scheme}

Based on the results of crosstab in analogous color scheme between monthly routine expenditures (showing social economic status) with product price perceptions, it was discovered from 86 respondents SES C-D, the majority of 23 people or $20.9 \%$ stated the price in the category was quite expensive. While from 24 people SES A-B, the majority as many as eight people or $7.3 \%$ have perception of product price in the very expensive category.

Of 86 respondents SES C-D, as many as 21 people or $19.1 \%$ have a quality perception of analog color schemes in good category. While from 24 people
SES A-B, as many as six people or $5.5 \%$ have the perception of analog color scheme packaging quality in the category of very good quality. The majority of 23 people or $20.9 \%$ has stated that they were very interested in the product with analog color scheme packaging. While from 24 people SES A-B, the majority of seven people or $6.4 \%$ has said they were very interested in the product with analog color scheme packaging.

Of 86 respondents SES C-D, the majority of 16 people or $14.5 \%$ were neutral to the statement of wanting to try the product with analog color scheme packaging. While from 24 people SES A-B, the majority of six people or $5.5 \%$ stated they were interested to try products with analogous color scheme packaging. Furthermore, from 110 respondents both SES C-D and SES A-B, the majority of 31 people or $28.2 \%$ has quite agreed to buy the product in analogous color scheme packaging.

In analogous color schemes, expenditure or Social Economic Status (SES) has no significant relationship to perceptions of price and quality, as well as product preference, products trial, and purchase intention; even if the research takes the error rate of 5\% or $10 \%$. This is caused by the probability value which is greater than 0.10 (see Table 2).

\section{Complementary Color Scheme}

Based on crosstab results, between monthly routine expenditures (showing social economic status) with product price perceptions in complementary color packaging, it was found that as many as 20 people or $18.2 \%$ of the respondents of SES C-Ds stated the price was in the medium category and it was quite expensive. While the majority of respondents SES A$\mathrm{B}$ has the perception of the price of products in the category of moderate as many as six people or $5.5 \%$.

The quality of products with complementary color packaging was perceived in the good category by 30 people or $27.3 \%$ of respondents either from SES AB or C-D. Of the 86 respondents SES C-D, the majority of 18 people or as much as $16.4 \%$ said they were very interested in products with complementary color scheme packaging. While from 24 people SES A-B, the majority of nine people or $8.2 \%$ has expressed quite interest in products with complementary color scheme packaging.

Of the 86 respondents SES C-D, the majority of 22 people or $20.0 \%$ stated neutral to the desire to try products with complementary color scheme packaging. While from 24 people SES A-B, the majority of 8 people or $7.3 \%$ has quite agreed on wanting to try 
products with complementary color scheme packaging. Furthermore, of 86 respondents SES C-D, the majority of 22 people or $20.0 \%$ stated neutral to the desire to buy products with complementary color scheme packaging. While from 24 people SES A-B, the majority of eight people or $7.3 \%$ has quite agreed on wanting to buy products with complementary color scheme packaging.

In complementary color schemes, expenditure or Social Economic Status (SES) has no significant relationship to perception of price and quality, as well as product preference, product trial, and purchase intention; even if the research takes the error rate of 5\% or $10 \%$ because the probability value is greater than 0.10 (see Table 2).

\section{One-Way ANOVA Test}

One-way ANOVA (Analysis of Variance) was conducted using two colors (white and yellow) and color scheme (monochrome, analogous and complementary) as independent variables to analyze whether there is a significant difference between price perception, perceived quality, product interest, product trial, and purchase intention in different color scheme of PDP packaging. The tendency of buyers was viewed from the respondent's perception of alternative answers on each variable. Based on the calculation, the sig value of the sample is greater than 0.05 . It can be concluded that the population variant is homogeneous, so it can be tested one-way ANOVA because it does not meet the provisions of the ANOVA test requirements.

Based on the calculation, $F_{\text {table }}$ for sig value 0.05 , total sample of 110 and the number of variables 5 , it was obtained $F_{\text {table }}$ of 2.296. Based on data processing (Table 3), $F_{\text {count }}>F_{\text {table. }}$. This means, there is a significant difference in the perception of price, quality, product preference, product trial, and purchase intention in different color schemes. Furthermore, the post hoc tests were conducted to determine which groups have differences.

Table 3

ANOVA

\begin{tabular}{|c|c|c|c|c|c|}
\hline & $\begin{array}{r}\text { Sum of } \\
\text { Squares }\end{array}$ & $d f$ & $\begin{array}{r}\text { Mean } \\
\text { Square }\end{array}$ & $F_{\text {count }}$ & $\overline{\text { Sig. }}$ \\
\hline Price perception & 46.956 & 4 & 11.739 & 4.959 & .001 \\
\hline $\begin{array}{l}\text { Quality } \\
\text { perception }\end{array}$ & 25.080 & 4 & 6.270 & 2.972 & .019 \\
\hline $\begin{array}{l}\text { Product } \\
\text { preference }\end{array}$ & 72.036 & 4 & 18.009 & 5.346 & .000 \\
\hline Product Trial & 63.771 & 4 & 15.943 & 4.447 & .002 \\
\hline $\begin{array}{l}\text { Purchase } \\
\text { intention }\end{array}$ & 31.829 & 4 & 7.957 & 2.339 & .054 \\
\hline
\end{tabular}

\section{Post Hoc Test of Price Perception}

Based on Table 4, there are significant differences in price perception on the dominant white color with the price group of monochrome color schemes and analog color schemes. The dominant price of white has a lower average price, which is -0.718 compared to the monochrome color scheme group. Similarly, the average price of the dominant group of white color has a lower average price of -0.591 from the price average of analogous color scheme group. While in the price group with the dominant yellow and complementary scheme does not have a significant difference in prices with the average price of the dominant white color.

In the dominant yellow, there was a significant difference between the average price of monochrome color schemes. The dominant group of yellow has a lower average price, that is -0.591 of the monochrome color scheme group. As for the dominant group of white, complementary, and analog schemes there is no significant difference in the average price.

In the monochrome color scheme, there were significant differences with dominant groups of white, yellow, and complementary color. The average price of the dominant group of monochrome color has a higher average price that is 0.718 of the dominant group of white, 0.591 of the dominant group of yellow and 0.636 of the dominant group of complementary colors. While in the analog color scheme group there is no significant difference in the average price.

In the analogous color schemes, there was a significant difference between the average price of the dominant group of white color. The average price of the analogous scheme color group has a higher average price, which is 0.591 of the dominant group of white. While in the dominant group of yellow, the monochrome color scheme and complementary there was no significant differrence in the price of the price.

In the complementary color schemes, there was a significant difference between the average price of monochrome color schemes. The average price of the complementary color scheme group has a lower average price, that is -0.636 of the monochrome color scheme group. While in the dominant group of white yellow and analog color schemes, there was no significant difference in average prices.

Based on Table 5, for the price aspect, dominant white group has the lowest average price, that is equal to 5.64. Meanwhile, the group of complementary color schemes is 5.72. The dominant group of yellow is 5.76 and the analog color scheme group is 6.23. Lastly, the monochrome color scheme group is 6.35 . It can be 
Table 4

Multiple Comparison

\begin{tabular}{|c|c|c|c|c|c|c|c|c|c|c|c|}
\hline \multicolumn{2}{|c|}{ color_schemes } & \multicolumn{2}{|c|}{ on price } & \multicolumn{2}{|c|}{ on quality } & \multicolumn{2}{|c|}{$\begin{array}{l}\text { on Product } \\
\text { preference }\end{array}$} & \multicolumn{2}{|c|}{ on Product Trial } & \multicolumn{2}{|c|}{$\begin{array}{c}\text { on Purchase } \\
\text { intention }\end{array}$} \\
\hline $\mathbf{a}$ & b & $\begin{array}{c}\text { mean diff } \\
(\mathbf{a}-\mathbf{b})\end{array}$ & Sig. & $\begin{array}{c}\text { mean diff } \\
(\mathbf{a}-\mathbf{b})\end{array}$ & Sig. & $\begin{array}{c}\text { mean diff } \\
(\mathbf{a}-\mathbf{b})\end{array}$ & Sig. & $\underset{(a-b)}{\text { mean diff }}$ & Sig. & $\underset{(a-b)}{\text { mean diff }}$ & Sig. \\
\hline \multirow{4}{*}{$\frac{\mathscr{2}}{3}$} & yellow & -0.127 & 0.973 & 0.018 & 1 & 0.082 & 0.997 & 0.245 & 0.872 & -0.009 & 1 \\
\hline & monochrome & $-0.718^{*}$ & 0.005 & -0.227 & 0.774 & $-0.691^{*}$ & 0.043 & -0.300 & 0.766 & -0.245 & 0.861 \\
\hline & analog & $-0.591^{*}$ & 0.037 & -0.027 & 1 & -0.127 & 0.986 & 0.236 & 0.887 & 0.109 & 0.992 \\
\hline & complementary & -0.082 & 0.995 & 0.427 & 0.188 & 0.418 & 0.441 & $0.736^{*}$ & 0.033 & 0.491 & 0.28 \\
\hline \multirow{4}{*}{$\frac{3}{0}$} & white & 0.127 & 0.973 & -0.018 & 1 & -0.082 & 0.997 & -0.245 & 0.872 & 0.009 & 1 \\
\hline & monochrome & $-0.591^{*}$ & 0.037 & -0.245 & 0.72 & $-0.773^{*}$ & 0.016 & -0.545 & 0.206 & -0.236 & 0.877 \\
\hline & analog & -0.464 & 0.168 & -0.045 & 0.999 & -0.209 & 0.916 & -0.009 & 1 & 0.118 & 0.99 \\
\hline & complementary & 0.045 & 0.999 & 0.409 & 0.226 & 0.336 & 0.654 & 0.491 & 0.306 & 0.500 & 0.262 \\
\hline \multirow{4}{*}{$\begin{array}{l}\text { : } \\
\text { : } \\
\overline{0} \\
\bar{\Xi} \\
\Xi\end{array}$} & white & $0.718^{*}$ & 0.005 & 0.227 & 0.774 & $0.691^{*}$ & 0.043 & 0.300 & 0.766 & 0.245 & 0.861 \\
\hline & yellow & $0.591^{*}$ & 0.037 & 0.245 & 0.720 & $0.773^{*}$ & 0.016 & 0.545 & 0.206 & 0.236 & 0.877 \\
\hline & analog & 0.127 & 0.973 & 0.200 & 0.846 & 0.564 & 0.154 & 0.536 & 0.221 & 0.355 & 0.611 \\
\hline & complementary & $0.636^{*}$ & 0.019 & $0.655^{*}$ & 0.008 & $1.109^{*}$ & 0 & $1.036^{*}$ & 0.001 & $0.736^{*}$ & 0.026 \\
\hline \multirow{4}{*}{ 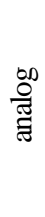 } & white & $0.591^{*}$ & 0.037 & 0.027 & 1 & 0.127 & 0.986 & -0.236 & 0.887 & -0.109 & 0.992 \\
\hline & yellow & 0.464 & 0.168 & 0.045 & 0.999 & 0.209 & 0.916 & 0.009 & 1 & -0.118 & 0.99 \\
\hline & monochrome & -0.127 & 0.973 & -0.200 & 0.846 & -0.564 & 0.154 & -0.536 & 0.221 & -0.355 & 0.611 \\
\hline & complementary & 0.509 & 0.103 & 0.455 & 0.140 & 0.545 & 0.180 & 0.500 & 0.288 & 0.382 & 0.54 \\
\hline \multirow{4}{*}{ 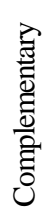 } & white & 0.082 & 0.995 & -0.427 & 0.188 & -0.418 & 0.441 & $-0.736^{*}$ & 0.033 & -0.491 & 0.28 \\
\hline & yellow & -0.045 & 0.999 & -0.409 & 0.226 & -0.336 & 0.654 & -0.491 & 0.306 & -0.500 & 0.262 \\
\hline & monochrome & $-0.636^{*}$ & 0.019 & $-0.655^{*}$ & 0.008 & $-1.109^{*}$ & 0 & $-1.036^{*}$ & 0.001 & $-0.736^{*}$ & 0.026 \\
\hline & analog & -0.509 & 0.103 & -0.455 & 0.140 & -0.545 & 0.180 & -0.500 & 0.288 & -0.382 & 0.54 \\
\hline
\end{tabular}

concluded that respondents evaluate the use of monochrome color schemes tends to have higher price perception than the dominant groups of white, complementary, yellow, and analog. While the dominant use of white color has the opposite tendency (perception of cheaper price).

\section{Post Hoc Quality Perception Test}

Based on Table 4, it can be seen that there are significant differences between the quality groups in monochrome color schemes with the quality groups in complementary color schemes. Monochrome color scheme quality has a higher average price, which is equal to 0.655 from the complementary color scheme group. Whereas for the dominant groups of white, yellow and analog schemes there is no significant differences in average quality.
For the quality aspect, the complementary color scheme has the lowest average price, which is equal to 6.18 . While the group of yellow color schemes has 6.59. The dominant white group has 6.61 and the analog color scheme group has 6.64. Finally, the monochrome color scheme group has 6.84. It can be concluded that the respondents assess the use of monochrome scheme color has a higher quality tendency. In complementary, the use of complementary color schemes tends to have lower quality perceptions than the dominant groups of yellow, white, analog, and monochrome (See Table 5).

\section{Post Hoc Test Oneway for Product Preference}

Based on Table 4, in the monochrome color scheme, there is a significant difference with the dominant group of white, yellow, and complementary 
Table 5

Tukey HSD Homogeneous Subsets

\begin{tabular}{|c|c|c|c|c|c|c|c|c|c|c|c|c|}
\hline & \multirow[t]{2}{*}{$N$} & \multicolumn{3}{|c|}{ on price } & \multicolumn{2}{|c|}{ on quality } & \multicolumn{2}{|c|}{$\begin{array}{l}\text { on product } \\
\text { preference }\end{array}$} & \multicolumn{2}{|c|}{ on product trial } & \multicolumn{2}{|c|}{$\begin{array}{c}\text { on purchase } \\
\text { intention }\end{array}$} \\
\hline & & 1 & 2 & 3 & 1 & 2 & 1 & 2 & 1 & 2 & 1 & 2 \\
\hline$\overline{\mathrm{W}}$ & 110 & 5.64 & & & 6.61 & 6.61 & 6.32 & & 6.24 & & 5.74 & $\overline{5.74}$ \\
\hline $\mathrm{C}$ & 110 & 5.72 & 5.72 & & 6.18 & & 5.90 & & 5.50 & & 5.25 & \\
\hline $\mathrm{Y}$ & 110 & 5.76 & 5.76 & & 6.59 & 6.59 & 6.24 & & 5.99 & 5.99 & 5.75 & 5.75 \\
\hline A & 110 & & 6.23 & 6.23 & 6.64 & 6.64 & 6.45 & 6.45 & 6.00 & 6.00 & 5.63 & 5.63 \\
\hline \multirow[t]{2}{*}{ M } & 110 & & & 6.35 & & 6.84 & & 7.01 & & 6.54 & & 5.98 \\
\hline & & 0.973 & 0.103 & 0.973 & 0.140 & 0.720 & 0.180 & 0.154 & 0.288 & 0.206 & 0.262 & 0.611 \\
\hline
\end{tabular}

N: Number, W: White; C: Complementary; Y: Yellow; A: Analogous; M: Monochrome; Subset for alpha $=0.05$

scheme. The dominant group of monochrome color has a higher average product preference, which is 0.691 from the dominant group of white, 0.773 from the dominant group of yellow and 1.109 from the dominant group of complementary colors. While in the analog color scheme group there was no significant difference in the mean of product preferences. In the analogous color schemes, there was no significant difference in the average of product preferences for dominant in white and yellow, as well as monochrome and complementary color schemes.

For the interest aspect of product preference, complementary scheme color group has the lowest product preference average, that is 5.90. The dominant yellow group is 6.24. The dominant white group is 6.32 and the analog color scheme group is 6.45. Lastly, the monochrome color scheme group is 7.01. It can be concluded that the respondents evaluate the use of monochrome color schemes tends to have an aspect of interest in a product higher than the dominant group of white, yellow, and analog. While the use of complementary colors has the opposite tendency (See Table 5).

\section{Post Hoc Test Desire of Product Trial}

Based on Table 4, in the dominant yellow, there is no significant difference in the average of desire to try products or product trials to the dominant white color, as well as monochrome, analog and complementary color schemes. Similarly, in the analogous color schemes, there was no difference in the average desire to try the product which is significant to the dominant color of white and yellow, and the monochrome color scheme and complementary colors.

In the complementary color schemes, there is a significant difference between the average desire to try the dominant product of white and monochrome color schemes. The average desire for a complementary color scheme product group has an average desire to try a lower product, which are -0.736 of the dominant white group and -1.036 of the monochrome color scheme group. While in the dominant group of yellow and analog color there is no significant difference in the average desire to try a product.

For the aspect of the desire to try the product, the complementary color scheme has the lowest average price, which is 5.50 . The dominant yellow group is 5.99. The analog scheme group is 6.00 and the dominant white group is 6.24. Meanwhile, the monochrome color scheme group is 6.54 . It can be concluded that the respondents evaluate the use of monochrome color schemes tends to have higher aspect of desire to try a product compared to the dominant group of white, analog, yellow and complementary. While the use of a complementary color scheme has the opposite tendency (See Table 5).

\section{Post Hoc Test for Product Purchase Intention}

Based on Table 4, the differences in desire to buy or intention to buy are significant between groups in monochrome color schemes with complementary color scheme groups. The desire to buy products in monochrome color schemes has a higher average, which is 0.736 compared to the complementary color scheme group. While the dominant color of white, yellow, and analog schemes have no significant difference in the average desire to buy a product with the average group of monochrome color schemes.

The order of the average product purchase intention in each color scheme can be seen based on the table above. For the aspect of product purchase desire, the complementary color has the lowest average, which is equal to 5.25. The analogous color scheme group has 5.63. The dominant white group has 5.74 and the dominant yellow group has 5.75. Meanwhile, the monochrome color scheme group has an average number of 5.98. It can be concluded that the respondents evaluate the use of monochrome color 
schemes tends to have higher purchase intention than the dominant group of complementary colors, white analogs, and yellow. While the use of complementary color schemes has the opposite tendency (See Table 5).

\section{Conclusion and Implications}

This study is conducted to explore the color scheme perceived by adolescent consumers in term of price and quality, the relevance to the interest of the product, also the desire to try and purchase the product. Another objective is to identify the correlation between price and quality perceptions and product preference, product trial and purchase intention on adolescent consumers with Social Economic Status (SES). The analysis are using cross-tab test, chi square test, and ANOVA. The findings suggest that in different color schemes packaging, the expenditure and SES does not have any impact on the price, whether the price is high or low. Furthermore, this study has identified that the expenditure and SES has no significant difference in product preference, product trial, and purchase intention. There is still the possibility of the product being purchased. In other words, consumers might prefer, try and buy the food product regardless their income/ expenditure and the product price. Similarly, the expenditure and SES does not have significant differences in perceived quality, except for dominant white product packaging.

Based on the HSD tukey test on one-way ANOVA, it can be seen that the respondents rated the use of monochrome color schemes tends to have more expensive price perceptions and higher quality perceptions. While the dominant use of white color has a tendency of cheaper price perception. This is aligned with study by Ampuero and Vila (2006) who point out that light color mainly white is considered as accessible products and reasonably priced. The use of complementary color schemes tends to have lower quality perceptions than other color schemes, which confirms the study by Witkowska (2018). Similarly, higher results are discovered in the aspects of product interest, also the desire to try and to buy the product, the respondents agree that the use of monochrome color schemes tends to be higher than the dominant of white and yellow, as well as analogous and complementary color schemes in the packaging design. Surprisingly, this study contradicts with the prior research by Witkowska (2018) who propose packaging in analogous colors are more likely to be purchased.

This study contributes to the knowledge by adding insight about color combination in marketing, while other studies usually address the color (hue) solely. As consumer analyse the food product packaging prior purchasing, the findings of this study are beneficial for SMEs food producers to create better packaging design as a promotion strategy to boost sales. Designers can select a monochrome color combination to apply in packaging design for SMEs food products as the monochrome scheme perceived higher price and higher quality by consumers, therefore affect the preference, product trial and purchase intention. This confirms the study by Mirza and Ali (2017) who argue that purchase intention is influenced by the product price and quality.

It is unfortunate that the involvement of Visual Communication Design students in Bandung city and county on banana chips packaging limits the generalization of the invention for all products and segmentation. The respondents who are design students make these findings less generalisable to consumers. The design students are considered as experts especially in color study. For further research, it is advisable to examine the needs to apply different product category packaging to students from various disciplines and/ or respondents with different education background and Social-Economic Status (SES). This paper only describes the homogeneity test on SES. The homogeneity test should be tested on all control variables such as age, gender, and color preference on the study variables to ensure that these variables are not significant and to enhance the generalisability of the results. Another issue that the size of the sample, which is 110 participants, can be considered too small, given the number of variables tested and combinations presented to the respondents. Therefore, it is recommended to confirm these results in a larger sample.

For future study, intergroup analysis (e.g. three experiment groups, each group have specific flavour with five different colour schemes) can be considered. This would alter the quality of their responses as they would not be exposed with too many stimuli at the same time. In addition, this study still uses conventional quantitative data collection techniques in the form of questionnaires, although there are many new techniques in the characterization of sensory and profiling consumers, such as eye-tracking, brain-tracking/ electroencephalogram (EEG) and Big Data Analytics. Therefore, it would be appealing if the further research uses a scheme of eye-tracking and brain-tracking in the collection of data, especially related to the visual stimuli, which one of them is color. The Big Data analysis is the process of collecting, organizing and analyzing a large pool of data to obtain patterns and useful information in understanding information and also helping to identify the most important data for 
current and future business decisions (Miranda, 2014); especially in packaging design decisions as one of the brand identity and information media in product marketing.

\section{References}

Ampuero, O., \& Vila, N. (2006). Consumer perceptions of product packaging. Journal of Consumer Marketing, 23(2), 102-114. https://doi. org/10.1108/07363760610655032

Babolhavaeji, M., Vakilian, M. A., \& Slambolchi, A. (2015). The role of product color in consumer behavior. Advanced Social Humanities and Management, 2(1), 9-15.

Baxter, S. M., Ilicic, J., \& Kulczynski, A. (2018). Roses are red, violets are blue, sophisticated brands have a Tiffany Hue: The effect of iconic brand color priming on brand personality judgments. Journal of Brand Management, 25(4), 384-394. https://doi.org/10.1057/s41262-0170086-9

Beneke, J., Mathews, O., Munthree, T., \& Pillay, K. (2015). The role of package colour in influencing purchase intent of bottled water Implications for SMEs and entrepreneurs. Journal of Research in Marketing and Entrepreneurship, 17(2), 165192. https://doi.org/10.1108/JRME-05-2015-0030

Cunningham, M. K. (2017). The value of color research in brand strategy. Open Journal of Social Sciences, 05(12), 186-196. https://doi.org/10.42 36/jss.2017.512014

Dalgin, M. H., Sraiheen, A., \& Akcay, O. (2018). Gender differences in product color importance, color choice, and meaning of color: A crosscountry study. Journal of Business and Behavior Sciences, 30(1), 88-99.

DuPuis, S., \& Silva, J. (2011). Package design workbook. Gloucester, MA: Rockport Publishers.

Garaus, M., \& Halkias, G. (2020). One color fits all: Product category color norms and (a) typical package colors. Review of Managerial Science, 14, 1077-1099. https://doi.org/10. 1007/s11846018-0325-9

Gong, S. M., \& Lee, W. Y. (2019). Colour harmony of two-colour combinations using a 3D colour configuration. Coloration Technology, 135(4), 292-304. https://doi.org/10.1111/cote.12405

Graves, P. (2015). Consumer.ology: Mitos riset pasar, kebenaran tentang konsumen, dan psikologi berbelanja. Jakarta: PT Elex Media Komputindo.

Greiner, B., \& Stephanides, M. (2020). The economics of color: A null result. Retrieved from https://epub.wu.ac.at/7388/1/wp2020-02.pdf
Huang, L., \& Lu, J. (2016). The impact of package color and the nutrition content labels on the perception of food healthiness and purchase intention. Journal of Food Products Marketing, 22(2), 191-218. https://doi.org/10.1080/104544 46. 2014.1000434

Husić-Mehmedović, M., Omeragić, I., Batagelj, Z., \& Kolar, T. (2017). Seeing is not necessarily liking: Advancing research on package design with eyetracking. Journal of Business Research, 80, 145154. https://doi.org/10.1016/j.jbusres.2017.04.019

Ishihara, S. (1972). Test for colour-blindness. Tokyo, Japan: Kanehara Shuppan.

Javed, S. A., \& Javed, S. (2015). The impact of product's packaging color on customers' buying preferences under time pressure. Marketing and Branding Research, 2(November), 3-14. https://doi.org/10.19237/M BR.2015.01.01

Karthikeyan, C., \& Joy, R. (2018). An exploratory study on colour psychology in marketing: A techno-leadership perspective. International Journal of Research in Social Sciences, 8(9), 65-92.

Kauppinen-Räisänen, H., \& Jauffret, M. N. (2018). Using colour semiotics to explore colour meanings. Qualitative Market Research, 21(1), 101117. https://doi.org/10. 1108/QMR-03-2016-0033

Keller, K. L. (2013). Strategic brand management: Building, measuring, and managing brand equity. Global Edition. New Jersey, NJ: Pearson Education Limited.

Kim, Y. J. (2019). The influence of color on brand extension: Mediation role of processing style. Japanese Psychological Research, 1-11. https://doi.org/10.1111/jpr.12269

Klimchuk, M. R., \& Krasovec, S. A. (2012). Packaging design: Successful product branding from concept to shelf $\left(2^{\text {nd }} e d\right)$. New Jersey, NJ: John Wiley \& Sons.

Kotler, P., \& Keller, K. L. (2016). Marketing management (15th Ed.). New Jersey, NJ: Pearson Education.

Martinez, L. M., Silva, M., Martinez, L. F., \& Abreu, A. M. (2018). Colour contrast in packaging and consumer product perception. Proceedings of the International Colour Association (AIC) Conference 2018: Colour \& Human Comfort - Lisbon, Portugal, 353-360.

Mead, J. A., \& Richerson, R. (2018). Package color saturation and food healthfulness perceptions. Journal of Business Research, 82, 10-18. https://doi.org/10.1016/j.jbusres.201 7.08.015

Miranda, E. (2014). Big data analytics. Retrieved from https://sis.binus.ac.id/2014/04/14/big-data-analytics/ 
Mirza, B., \& Ali, M. (2017). An assessment of relationship among service quality, price perception and customer satisfaction in the formation of consumer's purchase intention. Kuwait Chapter of the Arabian Journal of Business and Management Review, 6(12), 10-21. http://dx.doi.org/10. $12816 / 0041751$

Mohebbi, B. (2014). The art of packaging: An investigation into the role of color in packaging, marketing, and branding. International Journal of Organizational Leadership, 3(2), 92-102. https://doi.org/10.33844/ijol. 2014.60248

Nielsen. (2013). Nielsen new approach for Indonesia socio economic status. Retrieved from http:// perpi.or.id/wp-content/uploads/2013/ 04/NielsenNew-Approach-for-Indonesia-Socio-EconomicStatus-to-share.pdf

--1---- (2017). ABCDE socio-economic classification:Specification for year 2018. Retrieved from http://www.nielsen-admosphere.eu/wp-con tent/uploads/2014/06/Nielsen-Admosphere-AB CDE-classification-specificat ion-2018.pdf

Ribeiro, A. P. L., Carneiro, J. de D. S., Ramos, T. D. M., Patterson, L., \& Pinto, S. M. (2018). Determining how packaging and labeling of Requeijão cheese affects the purchase behavior of consumers of different age groups. British Food Journal, 120(6), 1183-1194. https://doi.org/10. 1108/BFJ-02-2017-0081

Sangaji, E. M., \& Sopiah. (2013). Perilaku konsumen: Pendekatan praktis disertai himpunan jurnal penelitian. Yogyakarta: Penerbit ANDI.

Shakeel, A. (2015). The role of brand credibility on purchase intention on fast food sector in Pakistan. International Journal of Information, Business and Management, 7(4), 158-168.

Singh, R. K. (2018). The effect of packaging attributes on consumer perception. International Journal for Innovative Research in Multidisciplinary Field, 4(5), 340-346.

Singh, S. (2006). Impact of color on marketing. Management Decision, 44(6), 783-789. https://doi. org/10.1108/00251740610673332.
Swasty, W. (2015). Business model innovation for small medium enterprises. The Winners, 16(2), 85-95.

-- (2016). Branding: Memahami dan merancang strategi merek. Bandung: PT Remaja Rosdakarya.

Swasty, W., Koesoemadinata, M. I. P., Gunawan, A. N. S., \& Putri, M. K. (2019). Student's perception and preference of food package design: A pilot study. A paper presented in the $6^{\text {th }}$ Bandung Creative Movement 2019, Telkom University, Bandung, Indonesia.

Triedman, K. (2015). Color: The professional's guide: Understanding, appreciation and mastering color in art and design. USA: HOW Books

Velasco, C., Pathak, A., Woods, A. T., Corredor, A., \& Elliot, A. J. (2020). The relation between symmetry in food packaging and approach and avoidance words. Quarterly Journal of Experimental Psychology, 73(5), 654-663. https://doi. org/10.1177/17470218 19887172

Wahyudi, N., \& Satriyono, S. (2017). Mantra kemasan juara. Jakarta: PT Elex Media Komputindo.

Wei, S.-T., Ou, L.-C., Luo, L.-C., \& Hutchings, J. B. (2012). The relationship between visual perceptions and taste expectations using food colours. Predicting Perceptions: Proceedings of the 3rd International Conference on Appearance, April, 157-160. http:// opendepot.org/1085/

Windharto, A. (2014). Design development of food \& beverage product packaging for SMEs co in Java and West Nusa Tenggara, economic corridor. IPTEK Journal of Proceeding Series, 1(1), 420424. https://doi. org/10.12962/j23546026.y20 14 i1.394.

Witkowska, Z. A. (2018). The influence of colour contrast in packaging on consumer behaviour. Retrieved from https://run.unl.pt/bitstream/ 03 62/53140/1/Witkowska_2019.pdf

Yu, L., Westland, S., Li, Z., Pan, Q., Shin, M. J., \& Won, S. (2018). The role of individual colour preferences in consumer purchase decisions. $\mathrm{Co}$ lor Research and Application, 43 (2), 258-267. https://doi.org/10.1002/col.22 180. 